\title{
Enraizamento in vitro de clones de mamoeiro 'Tainung 01'
}

\author{
In vitro rooting of clones of papaya 'Tainung 01 '
}

\author{
Jeferson Pereira Ferreira ${ }^{2}$, Edilson Romais Schmildt ${ }^{3 *}$, José Augusto Teixeira do Amaral ${ }^{4}$, Omar Schmildt ${ }^{5}$ e \\ Adriel Lima Nascimento ${ }^{6}$
}

\begin{abstract}
Resumo - Objetivou-se neste trabalho verificar a variabilidade existente entre clones da geração $\mathrm{F}_{2}$ de mamoeiro 'Tainung 01' quanto ao enraizamento in vitro. Os clones foram obtidos pela multiplicação de explantes a partir de plantas da geração $F_{2}$ obtidas em casa de vegetação, mantendo-se a identificação durante três subcultivos. A porcentagem de enraizamento e o crescimento de ramos foram avaliados a partir de ramos de 10 clones de mamoeiro 'Tainung 01' em meio de enraizamento contendo sais e vitaminas do meio MS, acrescido de $0,2 \mathrm{mg} \mathrm{L}^{-1}$ de AIB. O delineamento experimental foi inteiramente casualizado, com três repetições e 10 ramos por repetição individualizados em tubos de ensaio de $25 \times 150 \mathrm{~mm}$. Pelos resultados obtidos verificou-se que é possível selecionar clones mais responsivos à rizogênese in vitro de 'Tainung 01' a partir de segregantes da geração $\mathrm{F}_{2}$. A seleção dos clones mais responsivos para estabelecimento de protocolos comerciais depende da avaliação em campo, em decorrência da segregação para as características produtivas obtidas na geração $\mathrm{F}_{2}$.
\end{abstract}

Palavras-chave - Carica papaya. Genótipos. Micropropagação. Cultura de tecidos.

\begin{abstract}
The purpose of this study was to assess the variability among clones $\mathrm{F}_{2}$ geration of papaya 'Tainung 01 ' on the in vitro rooting. The clones were obtained by the multiplication of explants from the $\mathrm{F}_{2}$ geration plants obtained in a greenhouse, keeping the identification during three subcultures. The percentage of rooting and shoot growth were evaluated from branches of 10 clones of papaya Tainung $01^{\prime}$ in rooting medium containing salts and vitamins of MS medium, plus $0.2 \mathrm{mg} \mathrm{L}^{-1}$ IBA. The experimental design was completely randomized, with three replications and 10 branches per repetition in individual test tubes of $25 \mathrm{~mm} \times 150 \mathrm{~mm}$. From the results it appears that it is possible to select clones more responsive to in vitro rooting 'Tainung 01 ' from the segregating $\mathrm{F}_{2}$ generation. The selection of clones more responsive to establishment of trade protocols depends on the field evaluation, due to segregation for yield traits obtained in the $\mathrm{F}_{2}$ generation.
\end{abstract}

Key words - Carica papaya. Genotypes. Micropropagation. Tissue culture.

\footnotetext{
* Autor para correspondência

${ }^{1}$ Recebido para publicação em 12/03/2010; aprovado em 29/03/2011

Trabalho de iniciação científica do primeiro autor, com recursos financeiros do CNPq

${ }^{2}$ Bolsista do PIBIC/CNPq, Graduando do Curso de Agronomia/UFES, São Mateus-ES, Brasil, jeferson.p.ferreira@hotmail.com

${ }^{3}$ Departamento de Ciências Agrárias e Biológicas, CEUNES/UFES, São Mateus-ES, Brasil, 29.932-540, edilsonschmildt@ceunes.ufes.br ${ }^{4}$ Departamento de Produção Vegetal, CCA/UFES, Alegre-ES, Brasil, jata@cca.ufes.br

${ }^{5}$ Bolsista PNPD/CAPES, Programa de Pós-Graduação em Agricultura Tropical/UFES, São Mateus-ES, Brasil, omar-schmildt@ig.com.br

${ }^{6}$ Bolsista do PIBIC/FAPES, graduando do Curso de Agronomia UFES, São Mateus-ES, Brasil, adriel_aln@hotmail.com
} 


\section{Introdução}

A produção de mamão representa uma importante atividade econômica para o Brasil, sendo que no ano de 2008 a participação brasileira foi de 1,9 milhão de toneladas equivalentes a cerca de $27,3 \%$ da produção mundial (FAO, 2009). O híbrido 'Tainung 01', do grupo Formosa, é um dos genótipos amplamente explorados no Brasil, totalizando $40 \%$ da área plantada no Estado do Espírito Santo (ALVES, 2003).

Em virtude da inexistência de protocolos de propagação assexuada do mamoeiro pelas técnicas convencionais, esta espécie tem sido propagada tradicionalmente via seminífera, apesar dos problemas genéticos que ele apresenta, principalmente quanto à herança do sexo das plantas (AGNIHOTRI et al., 2004). Para cultivares dos grupos 'Solo' e 'Formosa' essa segregação exige a eliminação das plantas femininas em plantios comerciais, por ocasião do início do florescimento (três a cinco meses após o plantio). Como não se conhece o sexo das plantas no início do plantio, os agricultores plantam pelo menos três mudas por cova, o que aumenta os custos de produção, além de afetar o desenvolvimento das plantas hermafroditas em razão da competição.

Na busca por alternativas à propagação seminífera, a micropropagação torna-se uma técnica importante para diversas espécies, sobretudo na fruticultura (ALMEIDA et al., 2002; BORGES et al., 2006; COSTA; ALOUFA, 2007; KABIR et al., 2007; NAND et al., 2004; ROCHA et al., 2008; VILLA et al., 2008). Para o mamoeiro, no entanto, a rizogênese é um dos entraves ao processo micropropagativo (AGNIHOTRI et al., 2004; ROHMAN et al., 2007; SCHMILDT et al., 2009; SCHMILDT et al., 2010; TEO; CHAN, 1994; YU et al., 2000). Segundo Teo e Chan (1994), é mais fácil induzir enraizamento em culturas como cálamo, citros e gengibre do que em mamoeiro.

O processo de enraizamento é muito complexo, incluindo fatores fisiológicos, bioquímicos e biológicos (fatores internos) que interagem com os fatores externos (RADMANN et al., 2002). A complexidade aumenta em função do genótipo e do meio de cultura (GEORGE et al., 2008). Além disso, é importante que junto com a formação de raízes, haja crescimento dos ramos. Taiz e Zaiger (2009) afirmam que em dicotiledôneas, este crescimento é estimulado quando ramos são tratados com auxinas entre $10^{-5}$ e $10^{-6} \mathrm{M}$. Kabir et al. (2007) comprovaram isto no enraizamento in vitro de ramos de mamoeiro 'Shahi' obtendo maiores percentuais de enraizamento e comprimento dos ramos com uso de AIB a $10^{-5} \mathrm{M}$.

Especificamente referente à variabilidade genética em mamoeiro, Chan e Teo (2002) verificaram diferenças no enraizamento in vitro de seis clones do híbrido 'Eksotika'.
Em trabalhos com a geração $\mathrm{F}_{2}$ de 'Tainung 01', Schmildt (1994) encontrou elevados coeficientes de variação para as diversas variáveis avaliadas na rizogênese in vitro e ex vitro. Estes valores elevados verificados pelo autor provavelmente sejam em função da estrutura genética, pois o mesmo trabalhou com uma mistura de plantas da geração $\mathrm{F}_{2}$, que apresentam elevada segregação.

Neste trabalho procurou-se verificar a variabilidade existente entre clones da geração $\mathrm{F}_{2}$ de mamoeiro 'Tainung 01' quanto ao enraizamento in vitro.

\section{Material e métodos}

O experimento foi conduzido no laboratório de Biotecnologia Vegetal do Centro Universitário Norte do Espírito Santo da Universidade Federal do Espírito Santo, localizada no município de São Mateus.

Foram obtidas em casa de vegetação 50 plantas da geração $F_{2}$ de mamoeiros 'Tainung 01', do grupo Formosa. Após oito semanas seus ápices foram removidos e estabelecidos in vitro em meio de cultura, conforme Schmildt et al. (2007a). Mantendo-se a identidade, os explantes reativos foram recultivados para meio de multiplicação e subcultivados por três vezes em meio proposto por Schmildt et al. (2007a).

Os explantes utilizados para o experimento foram ramos do terceiro subcultivo padronizados em tamanhos de 1,5 $\pm 0,2 \mathrm{~cm}$ obtidos a partir dos 10 clones que apresentaram a melhor taxa de multiplicação medida nos dois subcultivos iniciais. Para melhor padronização do experimento e maior eficiência do enraizamento, os ramos foram excisados logo abaixo de um segmento nodal, conforme proposto por Schmildt (1994).

Para a fase de enraizamento os ramos foram inoculados em tubos de ensaio de $25 \times 150 \mathrm{~mm}$ contendo 20 $\mathrm{ml}$ de meio de cultura MS (MURASHIGE; SKOOG, 1962) acrescido de 1,0 $\mu \mathrm{mol} \mathrm{L}^{-1}$ de AIB, conforme Schmildt et al. (2007b). Em sala de cultivo, os explantes foram mantidos por 30 dias sob lâmpadas fluorescentes fornecendo 25,2 $\mu \mathrm{mol} \mathrm{m} \mathrm{m}^{-2} \mathrm{~s}^{-1}$ de fluxos de fótons fotossintéticos, 16 horas de fotoperíodo e temperatura de $27 \pm 2{ }^{\circ} \mathrm{C}$.

$\mathrm{O}$ experimento foi realizado em um delineamento inteiramente casualizado, com três repetições. Os tratamentos foram constituídos por 10 clones e cada parcela conteve 10 ramos, dispostos individualmente nos tubos de ensaio. Ao final de 30 dias foram determinadas a porcentagem de enraizamento e o crescimento de ramos. Os dados foram submetidos à análise de variância, bem como foram aplicados teste de média Tukey, coeficiente de correlação genotípica e correlação de Pearson. 
As análises estatísticas foram feitas com auxílio do programa GENES (CRUZ, 2006).

\section{Resultados e discussão}

A Tabela 1 apresenta resultados daanálise devariância onde se verifica que houve diferença estatisticamente significativa para enraizamento (ENR) e crescimento de ramos (CR). Os coeficientes de variação $(\mathrm{CV})$ foram 25,91 e 21,60\%, para ENR e CR, respectivamente. Estes CV são considerados baixos para trabalhos desta natureza. A padronização dos ramos associada à estrutura genética de genótipo único para cada clone, certamente contribuíram para estes resultados. Schmildt (1994) trabalhando com enraizamento in vitro de geração $\mathrm{F}_{2}$ de 'Tainung 01 ' obteve $\mathrm{CV}$ de mais de $300 \%$ para algumas variáveis avaliadas. A razão desse $\mathrm{CV}$ elevado foi decorrente da mistura de ramos de vários genótipos da geração $\mathrm{F}_{2}$.

Tabela 1 - Resultados da análise de variância e coeficiente de determinação genotípica $\left(\mathrm{h}^{2}\right)$ do enraizamento (ENR) e do crescimento de ramos (CR), e correlação de Pearson (r) entre ENR e CR para 10 clones de mamoeiro 'Tainung 01 ' geração $F_{2}$ cultivados in vitro

\begin{tabular}{lccc}
\hline \multirow{2}{*}{ FV } & \multirow{2}{*}{ GL } & \multicolumn{2}{c}{ QM } \\
\cline { 3 - 4 } & & ENR $(\%)$ & CR $(\mathrm{cm})$ \\
\hline Clone & 9 & $1102,22 * *$ & $9,63 * *$ \\
Resíduo & 20 & 163,33 & 0,19 \\
\hline Média Geral & 49,33 & 2,06 \\
CV (\%) & 25,91 & 21,60 \\
$\mathrm{~h}^{2}(\%)$ & 85,18 & 97,95 \\
$\mathrm{r}_{\text {(ENR. CR) }}$ & \multicolumn{2}{c}{0,9514} \\
** Significativo ao nível de 1\% pelo teste $\mathrm{F}$
\end{tabular}

Os coeficientes de determinação genotípica foram superiores a 80\% para ENR e CR e a correlação entre estas variáveis foi de 0,9514 (TAB. 1). Estes valores denotam alta explicação genética para as diferenças entre os clones, tornando-se interessante para o processo de clonagem. Schmildt et al. (2007b) obtiveram correlação de 0,8737 entre enraizamento e alongamento de ramos, também trabalhando com 'Tainung 01 ' na geração $F_{1}$ e variando níveis de sacarose no enraizamento in vitro. Resultados semelhantes também foram obtidos por Kabir et al. (2007) para o mamoeiro 'Shahi'.

Pela Tabela 2 entende-se melhor o alto valor da correlação entre ENR e CR, quando se verifica a tendência de maior CR para os clones que apresentam maior ENR. Taiz e Zeiger (2009) explicam que há tendência do crescimento de ramos durante a rizogênese na presença de auxina entre $10^{-5}$ e $10^{-6}$ mol $\mathrm{L}^{-1}$ e esse crescimento se deve principalmente ao alongamento celular, em virtude da capacidade das auxinas promoverem a extensão da parede celular. Neste trabalho, utilizou-se AIB a $10^{-6}$ mol L-1, que também é concentração ótima para indução de raízes adventícias (TAIZ; ZAIGER, 2009).

Tabela 2 - Resultados da porcentagem de enraizamento (ENR) e crescimento de ramos (CR) para 10 clones de mamoeiro 'Tainung 01 ' geração $\mathrm{F}_{2}$ cultivados in vitro

\begin{tabular}{lll}
\hline \multirow{2}{*}{ Clone } & \multicolumn{2}{c}{ Média } \\
\cline { 2 - 3 } & ENR $(\%)$ & CR $(\mathrm{cm})$ \\
\hline T39 & $93,34 \mathrm{a}$ & $6,12 \mathrm{a}$ \\
T12 & $70,00 \mathrm{ab}$ & $4,17 \mathrm{~b}$ \\
T10 & $53,33 \mathrm{ab}$ & $1,87 \mathrm{~cd}$ \\
T26 & $46,67 \mathrm{~b}$ & $2,50 \mathrm{c}$ \\
T14 & $46,67 \mathrm{~b}$ & $0,97 \mathrm{~cd}$ \\
T01 & $43,33 \mathrm{~b}$ & $1,37 \mathrm{~cd}$ \\
T50 & $40,00 \mathrm{~b}$ & $0,60 \mathrm{~d}$ \\
T05 & $36,67 \mathrm{~b}$ & $1,60 \mathrm{~cd}$ \\
T43 & $33,33 \mathrm{~b}$ & $0,53 \mathrm{~d}$ \\
T35 & $30,00 \mathrm{~b}$ & $0,87 \mathrm{~d}$ \\
\hline DMS & 44,94 & 1,56 \\
\hline
\end{tabular}

As médias seguidas da mesma letra, na vertical, não diferem significativamente entre si pelo teste de Tukey ao nível de $1 \%$

OENR variou de $30,00 \%$ para o clone T35 até 93,34\% para o clone T39. Trabalhando com seis clones do híbrido Eksotika de mamoeiro, Chan e Teo (2002) verificaram uma variação de 58,3 a $88,1 \%$ no enraizamento in vitro. $\mathrm{O}$ enraizamento máximo verificado por outros autores para o 'Tainung 01' geração $\mathrm{F}_{1}$ foi em torno de 60\% (SCHMILDT et al., 2007b; SCHMILDT et al., 2009; SCHMILDT et al., 2010). Também trabalhando com 'Tainung 01', Schmildt (1994) obteve máximo de $65 \%$ de enraizamento de ramos, utilizando no estudo uma mistura de genótipos da geração $\mathrm{F}_{2}$. Yu et al. (2000) testando vários níveis de sais MS em meios de cultura in vitro, alcançaram enraizamento entre 17,8 e 71,1\% para o híbrido 'Tainung 02 '.

A variabilidade genética é explicada segundo George et al. (2008) pelo fato da regeneração de órgãos adventícios ser governada por genes nucleares que podem ser recessivos, dominantes ou aditivos.

Considerando que o enraizamento é um dos pontos cruciais no processo microprapagativo do mamoeiro (ROHMAN et al., 2007; SCHMILDT et al., 2009; SCHMILDT et al., 2010; YU et al., 2000), clones de 
'Tainung 01' geração $\mathrm{F}_{2}$ como o T12 e o T39 podem perfeitamente serem usados para clonagem in vitro, desde que sejam antes testados em campo e que se verifique a presença de padrão comercial para as características produtivas. Estes clones, além de apresentarem bom enraizamento, também apresentam bom crescimento de ramos o que tende a facilitar o manuseio das plantas durante o processo de aclimatação.

\section{Conclusões}

1. Existe variabilidade entre clones $\mathrm{F}_{2}$ de 'Tainung 01' quanto ao padrão de enraizamento in vitro;

2. Clones de maior porcentual de enraizamento podem ser investigados para micropropagação clonal.

\section{Agradecimentos}

À Fundação de Amparo à Pesquisa do Espírito Santo (FAPES), ao Conselho Nacional de Pesquisa (CNPq) e à Coordenação de Aperfeiçoamento de Pessoal de Nível Superior (CAPES) pelo apoio financeiro.

\section{Referências}

AGNIHOTRI, S. et al. In vitro cloning of female and male Carica papaya through tips of shoots and inflorescences. Indian Journal of Biotechnology, v. 03, n. 02, p. 235-240, 2004.

ALMEIDA, W. A. B. de et al. Optimization of a protocol for the micropropagation of pineapple. Revista Brasileira de Fruticultura, v. 24, n. 02, p. 296-300, 2002.

ALVES, F. L. A cultura do mamão Carica papaya no mundo, no Brasil e no Estado do Espírito Santo. In: MARTINS, D.S.; COSTA, A. F. S. A cultura do mamoeiro: tecnologias de produção. Vitória: Incaper, 2003. cap 1, p. 13-34.

BORGES, N. S. S. et al. Avaliação da descontaminação, germinação e respostas morfogenéticas do mamão cultivado in vitro (Carica papaya L.). Revista Ciência Agronômica, v. 37, n. 02, p. 308-313, 2006.

CHAN, L. K.; TEO, C. K. H. Micropropagation of Eksotika, a malaysian papaya cultivar, and the field performance of the tissue culture derived clones. Acta Horticulturae, n. 575, p. 99-105, 2002.

COSTA, N. M. de S.; ALOUFA, M. A. I. Desenvolvimento in vitro de embriões zigóticos de tamareira. Revista Ciência Agronômica, v. 38, n. 03, p. 206-279, 2007.

CRUZ, C. D. Programa GENES: biometria. Viçosa (MG): Editora UFV, 382 p. 2006.

FAO. Faostat. Disponível em: <www.faostat.fao.org $>$. Acesso em: 26 dez. 2009.
GEORGE, E. F.; HALL, M. A.; DE KLERK, G. J. Plant propagation by tissue culture: volume 1 . The background. $3 \mathrm{rd}$ ed. Dordrecht: Springer, 2008.

KABIR, A. H. et al. Effect of growth regulators and carbon souces on axillary shoot proliferation from shoot-tip explant and successful transplatation of papaya (Carica papaya L.). Biotechnology, v. 06, n. 02, p. 268-272, 2007.

MURASHIGE, T.; SKOOG, F. A revised medium for rapid growth and bioassays with tobaco tissue cultures. Physiologia Plantarum, v. 15, n. 03, p. 473-497. 1962.

NAND, N.; DREW, R. A.; ASHMORE, S. Micropropagation of two Australian native fruit species, Davidsonia pruriens and Davidsonia jerseyana G. Harden \& J. B. Williams. Plant Cell Tissue and Organ Culture, v. 77, n. 02, p. 193-201, 2004.

RADMANN, E. B.; FACHINELLO, J. C.; PETERS, J. A. Efeito de auxinas e condições de cultivo no enraizamento in vitro de porta-enxertos de macieira 'M-9'. Revista Brasileira de Fruticultura, v. 24, n. 03, p. 624-628, 2002.

ROCHA, M. A. C. et al. Enraizamento in vitro e aclimatização de genótipos de jenipapeiro (Genipa americana L.). Revista Brasileira de Fruticultura, v. 30, n. 03, p. 769-774, 2008.

ROHMAN, M. M. et al. Lateral bud culture of papaya (Carica papaya) for clonal propagation. Biotechnology, v. 06, n. 03, p. 339-343, 2007.

SCHMILDT, E. R. Enraizamento in vitro e ex vitro de ramos de mamoeiro (Carica papaya L.). 1994. 84f. Dissertação (Mestrado em Fitotecnia) - Universidade Federal de Viçosa, Viçosa.

SCHMILDT, O.; SCHMILDT, E.R.; AMARAL, J.A.T. do. Cinetina e ANA na multiplicação in vitro de mamoeiro 'Tainung 01'. Scientia Agraria, v. 08, n. 01, p. 55-60. 2007a.

SCHMILDT, E. R.; AMARAL, J. A. T.; SCHMILDT, O. Sacarose na fase de enraizamento in vitro de mamoeiro 'Tainung 01'. Scientia Agraria, v. 08, n. 01, p. 25-30, 2007 b.

SCHMILDT, E. R. et al. Resposta rizogênica in vitro de ápices caulinares de mamoeiro 'Tainung 01' em diferentes tempos de permanência em meios de indução e regeneração. Acta Scientiarum - Agronomy, v. 31, n. 04, p. 695-700, 2009.

SCHMILDT, E. R. et al. Níveis de ácido indol butírico (AIB) no enraizamento in vitro de microestacas de mamoeiro 'Tainung 01'. Acta Scientiarum - Agronomy, v. 32, n. 01, p. 125-129, 2010.

TAIZ, L.; ZEIGER, E. Fisiologia vegetal. 4. ed. Porto Alegre: Artmed. 2009.

TEO, C. K. H.; CHAN, L. K. The effects of agar content, nutrient concentration, genotype and light intensity on the in vitro rooting of papaya microcuttings. The Journal of Horticultural Science, v. 69, n. 02, p. 267-73, 1994.

VILLA, F. et al. Crescimento in vitro de amoreira-preta: efeito de reguladores de crescimento e da cultivar. Ciência e Agrotecnologia, v. 32, n. 06, p. 1754-1759, 2008.

YU, T. A. et al. Efficient rooting for establishment of papaya plantlets by micropropagation. Plant Cell Tissue and Organ Culture, v. 29, n. 01, p. 29-35, 2000. 